\title{
Pemanfaatan Batu Sungai Melli Kecamatan Baebunta Kabupaten Luwu Utara Dalam Campuran AC-WC
}

\author{
Deamayes $^{\star 1}$, Alpius ${ }^{\star 2}$, Charles Kamba*3 \\ *1 Mahasiswa Program Studi Teknik Sipil, Universitas Kristen Indonesia Paulus, Makassar, Indonesia \\ deamayes5@gmail.com \\ *2, Dosen Program Studi Teknik Sipil, Universitas Kristen Indonesia Paulus, Makassar, Indonesia \\ alpiusnini@gmail.com dan \\ *3, Dosen Program Studi Teknik Sipil, Universitas Kristen Indonesia Paulus, Makassar, Indonesia \\ kamba.charles@gmail.com
}

\begin{abstract}
ABSTRAK
Penelitian ini memanfaatkan agregat Sungai Meli untuk mengetahui konfigurasi campuran AC-WC serta dapat mengetahui karakteristik dari Marshall, Stabilitas Marshall yang tersisa pada campuran "AC-WC" dengan Spesifikasi Umum 2018 (Revisi 6) Departemen Umum Republik Indonesia dan Standar Pengujian SNI. Metode yang dibuat pada penelltian berupa karakteristik agregat halus, filler, agregat kasar serta aspal kemudian menyusun konfigurasi campuran lalu membentuk benda uji, serta pengujian Marshall Konvensional. Dalam pembuatan benda uji metode KAO digunakan untuk mendapatkan Stabilitas Marshall Sisa (SMS). Hasil penelitian menunjukkan rencana konfigurasi yang terdapat dalam campuran "AC-WC" yang memakai bahan Sungai Melli, merupakan, agregat halus 50,30\%, filler 5,80\%, agregat kasar $36,90 \%$, dengan ketentuan ukuran kadar aspal minimum 7,00\%. dan nilai akhir dari pengujian Marshall Immersion (Stabilitas Marshall Sisa) dengan campuran Laston Lapis Aus yang memakai agregat Sungai Melli mematuhi persyaratan Umum Bina Marga 2018, yaitu 97,72\% > $90 \%$.
\end{abstract}

Kata kunci: Campuran AC-WC, Agregat Sungai Melli.

\section{ABSTRACT}

This study utilizes the Meli River aggregate to determine the configuration of the AC-WC mixture and to know the characteristics of Marshall, the remaining Marshall stability in the AC-WC mixture with the 2018 General Specifications of the General Department of the Republic of Indonesia and SNI Testing Standards. The method of research consists of fine aggregate, filler, coarse aggregate and asphalt, then arranging the mixing configuration and forming test objects, as well as Conventional Marshall testing. The KAO method was used to obtain the remaining Marshall Stability. The result showed that the configuration plan contained in the AC-WC mixture using the Melli River material, was fine aggregate $50.30 \%$, nfiller $5.80 \%$, coarse aggregate $36.90 \%$, with a minimum size of $7.00 \%$ asphalt content. and value of the Remaining Marshall Stability with a mixture of AC-WC using Melli River aggregate, complies with the 2018 General Bina Marga requirements, namely $97.72 \%>90 \mathrm{n} \%$.

Keywords: AC-WC mixture, Melli River Aggregate.

\section{PENDAHULUAN}

Batu Sungai Melli saat ini banyak digunakan sebagai agregat untuk campuran konstruksi, seperti konstruksi penimbunan jalan dan pondasi. Meningkatnya suatu pembangunan kostruksi jalan maka mengaklbatkan kebutuhan bahan semakln banyak digunakan, seperti penggunaan agregat batu sungai Melli, sehingga banyak agregat yang ddidatangkan dari wilaya lain. Pembangunan jalan pada daerah Melli setiap tahunnya meningkat, dalam rangka untuk membantu pembangunan agar merata ke daerah yang terpencil.

Pemerintah Daerah mendorong menggunakan material yang ada di lokasi sekitar guna untuk memanfaatkan potensi alam dari daerah tersebut, mengingat bahwa pelaksanaan pekerjaan akan lebih lama apabila mendatangkan bahan-bahan dari luar daerah, sehingga akan sangat efisien apabila menggunaan material lokal daerah tersebut namun harus diuji terlebih dahulu mutu dan kualitasnya. Penggunaan batu sungai Melli belum dimanfaatkan sebagai bahan penyusunan lapisan perkerasan jalan dan secara spesifik mengenai campuran AC-WC. Dalam penulisan skripsi ini dapat Memanfaatan Agregat dari sungai Melli untuk diteliti dengan cara pengujian karakteristik Agregat dan Nilai Stabilitas Marshall Sisa, dimana fungsi dari AC-WC yaitu sebagai lapisan pelindung dan kedap air. Setelah mengetahui pentingnya AC-WC baik atau tidak digunakan dalam penelitian ini penulis dapat mengetahui karakteristik dan komposisi yang digunakan karena dalam campuran beraspal sangat berpengaruh pada kualitas campuran yang dihasilkan untuk menghasilkan campuran beraspal yang mengetahui 
spesifikasinya sesuai dengan fungsinya. Pada awalnya campuran untuk masing-masing agregat yang dipergunakan beragam untuk masing-masing pencampuran, untuk itu kriterian agregat sangat mempengaruhi sejumlah kriteria campuran itu sendiri, maka dari itu dilaksanakan pemeriksaan atau percobaan untuk berbagai jenis agregat untuk mendapatkan hasil stabilitas yang telah memenuhi dan mempunyai persyaratan spesifikasi. Dalam memanfaatan agregat Sungai Melli, yang menjadi awal dalam melaksanakan suatu percobaan yaitu mencari tahu sampai dimana pemanfaatan penggunaan agregat dari Sungai Melli, Kecamatan Baebunta baik digunakan dalam campuran ACWC.

Lapisan Permukaan adalah lapisan yang mempunyai hubungan yang langsung dengan beban dalam hal ini roda kendaraan. Lapis di permukaan termasuk sebagai lapis aus, namun tidak menutup kemungkinan terdapat beberapa lapisan permukaan ditambah dengan lapis aus.

Lapis dari permukaan dalam susunan perkerasan lentur terdapat campuran mineral agregat dan bahan perekat yang diposisikan untuk lapisan yang teratas dan seperti biasa terdapat di atas lapis pondasi. Bahan untuk lapis permukaan pada dasarnya mirip dengan bahan dalam lapis pondasi dengan syarat-syarat yang lebih tinggi. Dalam menggunakan bahan aspal dibutuhkan agar supaya lapisan tersebut bisa berkarakter kedap air, disamping itu bahan aspal itu sendiri menyediakan bantuan tegangan tarik, yang memiliki arti membuat tinggi kekuatan dukung lapisan kepada beban roda.

Beberapa penelitian sebelumnya yang menggunakan agregat Sungai Bittuang diperoleh nilai indeks kekuatan sisa $95,03 \%$, agregat dari Sungai Mawa untuk campuran AC-WC memiliki indeks kekuatan sisa 94,81\%.

Tujuan penelitian yaitu guna mencari tahu kriteriakriteria dari agregat, konfigrasi dan kriteria-kriteria campuran melewati pengecekan marshall konvesional dan hasil indeks kekuatan sisa dengan memakai pengujian marshal immersion.

\section{METODE}

Pengambilan material untuk penelitian berlokasi di Sungai Melli, Kecamatan Baebunta, Kabupaten Luwu Utara.

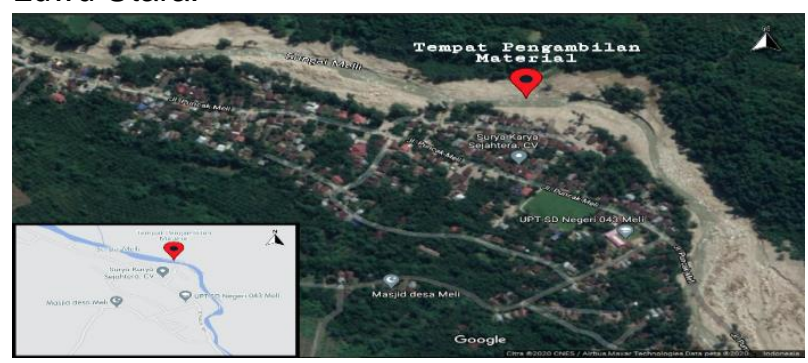

\section{Gambar 1. Lokasi pengambilan material}

\section{Pemeriksaan Karakteristik Agregat}

Pengujian Analisis Saringan berdasarkan SNI ASTM C136:2012 untuk mendapatkan distribusi ukuran agregat kasar dalam bentuk grafik.

Pengujian Berat Jenis Curah Bulk serta Penyerapan Air Agregat kasar berdasarkan metode SNI 1969:2016 serta Agregat Halus SNI 1970:2016 untuk mengetahui berat jenis (bulk), berat yang berjenis kering dengan permukaan jenuh Saturated Surface Dry, berat berjenis semu apparent, serta penyerapan dari ageragat kasar dan halus.

Pengujian Hasil yang bernilai Setara Pasir untuk mengetahui nilai Setara Pasir di agregat yang mempunyai nilai darl bahan-bahan agregat halus yang dipakai terhadap suatu lapisan perkerasan.

Pengecekan Keausan (Abration) pada Mesin Los Angeles untuk menentukan angka keausan agregat dengan menggunakan alat Los Angeles Abrasion Test dengan perbandingan berat benda yang lolos pada saringan No.12 $(1,7)$ dengan berat semula, dalam \%.

Pengujian partikel pipih dan Lonjong untuk mendapatan indeks kepipihan dan kelonjongan suatu agregat yang bisa dipakai pada campuran beraspal.

Percobaan kelekatan agregat untuk mengetahui tingkat kedekatan agregat akan aspal dengan proses kasat mata (visual).

Percoban Agregat Lolos Ayakan No .200/0,075 $\mathrm{mm}$ untuk menetapkan total bahan didalam agregat yang lolos dalam saringan Nomor 200 $0,075 \mathrm{~mm}$ dalam proses pencucian serta guna mendapatkan persentase dari jumlah bahan di dalam agregat yang berhasil saringan Nomor 200 $0,075 \mathrm{~mm}$.

\section{Pemeriksaan Karakteristik Aspal}

Percobaan Penetrasi pada $25^{\circ} \mathrm{C}$ untuk menetapkan kapasitas daya aspal dalam suatu jarum yang telah masuk kedalam aspal pada temperatur yang ditetapkan dan dibebani dengan beban selama periode yang ditentukan.

PercobaanTitik Nyala $\left({ }^{\circ} \mathrm{C}\right)$ untuk mengetahui temperatur yang mana aspal dimulai dengan mengeluarkan nyala api dan terbakar akibat pemanasan

Pemeriksaan Tiitik Lembek $\left({ }^{\circ} \mathrm{C}\right)$ untuk menetapkan temperatur di mana aspal mulai lembek. 
Percobaan Berat Jenis untuk mengetahui berat jenis aspal yang dipakai. Dimana berat jenis aspal merupakan perbandingan antar berat bitumen/terhadap air suling dengan isi pada suhu tertentu.

Pengujian Daktilitas dengan suhu $25^{\circ} \mathrm{C}$ untuk mencari tahu kekenyalan aspal yang ditunjukkan pada panjang suatu pemuluran aspal yang bisa tercapai hingga sebelum putus pada temperatur dan kecepatan tertentu.

Pemeriksaan Berat yang Hilang (\%)untuk mencri tahu kehilangan minyak pada aspal akibat pemanasan yang berulang dan pengujian ini juga berguna untuk mengukur perubahan daya kerja aspal yang diakibatkan dari kehilangan berat.

\section{Pemeriksaan Berat Jenis Filler}

Pemeriksaan Berat Jenis Filler mengacu pada standar rujukan SNI ASTM C136:2012 untuk menentukan berat jenis fiiller yang akan digunaakan sebagai bahan pengisi campuran aspal.

\section{Perencanaan Campuran}

Perencanaan komposisi pada campuran AC-WC yang dipakai adalah campuran aspal panas ( $\mathrm{Hot}$ mix) yaitu suatu campuran yang terdiri dari jenisjenis agregat dimana merupakan konfigurasi terbesar didalam campuran, spesifikasi gradasi yang dipakai ialah gradasi ideal atau memakai nilai/hasil tengah dari rentang gradasi yang dipakai. Setelah itu menghitung fraksi proporsi dari masing-masing fraksi dimana fraksi kasar, fraksi halus dan fraksi fiiller serta kebutuhan aspal campuran. Ukuran dari fraksi dilandaskan pada Departemen pekerjaan Umum,2018 Divisi 6

Tabel 1. Rancangan komposisi campuran

\begin{tabular}{ccc}
\hline $\begin{array}{l}\text { Ukuran } \\
\text { Ayakan } \\
(\mathrm{mm})\end{array}$ & $\begin{array}{l}\text { \% Berat yang Lolos Terhadap Total } \\
\text { agregat dalam Campuran AC-WC }\end{array}$ \\
& $\begin{array}{l}\text { Spesifikasi } \\
\text { Gradasi (\%) }\end{array}$ & $\begin{array}{l}\text { Rancangan } \\
\text { Gradasi } \\
\text { Campuran (\%) }\end{array}$ \\
$11 / 2$ & & 100 \\
\hline 1 & & 95 \\
$3 / 4$ & 100 & 83,5 \\
$1 / 2$ & $90-100$ & 61 \\
$3 / 8$ & $77-90$ & 43 \\
4 & $53-69$ & 30,5 \\
8 & $33-53$ & 22 \\
16 & $21-40$ & 15,5 \\
30 & $14-30$ & 10,5 \\
50 & $9-22$ & 6,5 \\
100 & $6-15$ & \\
200 & $4-9$ & \\
\hline
\end{tabular}

\section{Komposisi Campuran}

Perhitungan kadar aspal perkiiraan awal yaitu

Kadar aspal efektif minimum $=0,6 \%$

Kadar aspal efektif maksimum $=1,2 \%$

Lolos ayakan No. $200=6,5 \%$

Kadar aspal rancangan maksimum $=11 \%$

Kadar aspal rancangan minimum $=5 \%$

Perencanaan kadar aspal yang dipakai guna campuran ialah minimal $5 \%, 5,5 \%, 6 \%, 6,5 \%$ dan $7 \%$.

Berikut tabel jumlah benda uji yang digunakan untuk peneliitian ini seperti pada tabel 2 .

Tabel 2. Jumlah benda uji

\begin{tabular}{ccc}
\hline $\begin{array}{c}\text { Kadar } \\
\text { Aspal } \\
(\%)\end{array}$ & $\begin{array}{c}\text { Marshall } \\
\text { Konvensional }\end{array}$ & $\begin{array}{c}\text { Marshall } \\
\text { Immersion }\end{array}$ \\
\hline $5,0 \%$ & 3 & \\
$5,5 \%$ & 3 & 3 \\
$6,0 \%$ & 3 & \\
$6,5 \%$ & 3 & \\
$7,0 \%$ & 3 & 3 \\
Total & 15 & \\
\hline
\end{tabular}

\section{Pengujian Marshall Konvensional}

Pengujian ini dilaksanakan guna mencari tahu hasil akhir/nilai stabilitas dan kelelehan (flow), dan analisis kepadatan dan pori dari campuran padat yang terbentuk. Benda uji/ beton aspal padat dicetak dari gradasi agregat pada campuran tertentu,dengan

spesifikasi campuran. Sebelum membuat briket campuran aspal beton maka dikisarkan kadar aspal optimum dengan cara menggunakan rumus pendekatan. Pengujian Marshall Konvesional harus menuruti tata cara pada SNI 06-2489-1991 AASHTO T245-90. Parameter Marshall yang dihitung antara lain: "VIM, VMA, VFA, berat volume, dan parameter lain" seturut parameter yang ada pada spesifikasi campuran. seusai seluruh parameter briket didapatkan, untuk itu, digambar grafik terkait perhubungan kadar aspal dengan parameternya yang setelah itu bisa ditetapkan tingkat aspal optimumnya. tingkat aspal optimum yaitu nilai tengah aani rentang kadar aspal yang telah mematuhi uji Marshall modifikasi. Modifikasi alat Marshall terdapat pada bahan pemegang benda uji.

\section{Perencanaan Kadar Aspal Optimum}

Dalam merencanakan Kadar Aspal Optimum, diambil nilai tertiingi dari grafik dengan hubungan sstabilitas, kepaadatan campuran yang dipadatkan dengan tingkat aspal. Tingkat Aspal Optimum untuk campuran AC-WC fungsinya yaitu kedap air 
maka rongga dalam campuran atau void in mixture (VIM) besar karena tahan terhadap perendaman, maka VIM yang kecil akan lebih tahan jika terendam.

\section{Pengujian Marshall Immersion}

Percobaan ini berguna untuk mengetahui daya/kemampuan pada campuran terkait lama perendaman, suhu, dan air. Untuk tata cara pelaksnaan percobaan setara pula dengan tata cara percobaan pada Marshall dasar guna campuran Hot Mix, hanya perbedaannya terdapat pada total jangka waktu perendaman dimana pada Marshall Immersion janga waktu perendaman ialah 24 jam pada temperatur $60^{\circ} \mathrm{C}$.

\section{ANALISIS DAN PEMBAHASAN}

\section{Karakteristik Material}

\section{a. Agregat}

Hasil dari pemeriiksaan keausan agregat dengan Alat Abrasi Los Angeles, didapatkan niilai daya agregat kasar terkait keausan dari Fraksi A adalah 3,86\%, Fraksi B ialah 5,32\%, Fraksi C ialah 3,98\% dan Fraksi $D$ ialah 5,6\%. Agregat tersebut digunakan sebagai bahan-bahan lapisan dari permukaan jalan dan tahan kepada keausan yang diakibakan gesekan antar agregat dengan agregat / agregat dengan roda kendaraan.

Sesuai hasil percobaan berat jenis serta penyerapan agregat kasar yang sudah memakai 2 sampel, didapatkan nilai berat jenis bulk adalah 2,73 , berat jenis SSD adalah 2,77, berat jenis semu adalah 2,84 dan Penyerapan air adalah 1,51\%. Spesifikasi Bina Marga 2018, menetapkan bahwa untuk berat jenis bulk, berat jenis SSD dan berat jenis semu adalah minimal 2,5 dan penyerapannair maksimal 3\% bisa diperlihatkan bahwa penyerapan agregatnya sangat kecil.

Hasil percobaan berat jenis serta penyerapan agregat halus diperoleh berat jenis Bulk sebesar 2,63 , berat jenis SSD ialah 2,66, Berat macam semu ialah 2,71 dan penyerapan air ialah 1,11\%. Spesiifikasi dasar Bina Marga 2018, yaitu pada Berat Jenis Bulk, Berat Jenis, Berat Jenis Semu adalah minimal 2,5 dan Penyerapan Air maksimal ialah $3 \%$.

Berikut ini, grafik hasil dari percobaan analisis saringan bisa dilihat dibawah ini pada gambar 2 . Pada Gambar 2, ditampilkan grafik hasil akhir analisis saringan seperti gradasi agregat serta spesifikasinya, dimana gradasi terkait agregat yang terletak ditengah antara batas atas dan batas bawah. Dari percobaan material yang lolos saringan No. 200 sudah didapatkan nilai 2,41 dengan ketentuan-ketentuan yaitu optimal $10 \%$.

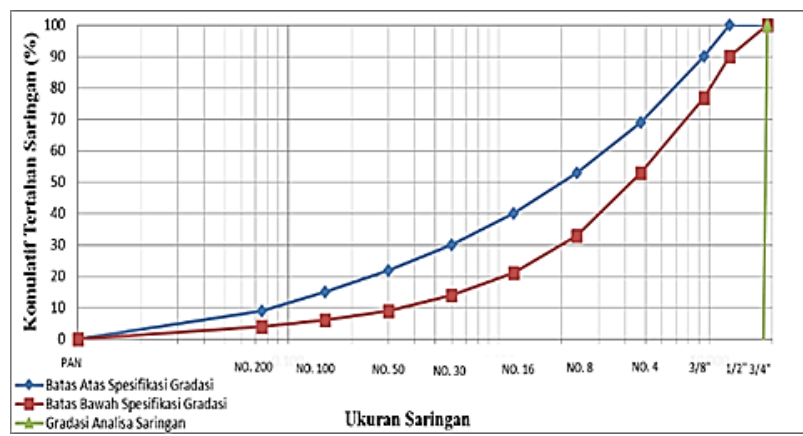

Gambar 2. Hasil pengujian analisa saringan

Percobaan pada tingkat lumpur agregat halus menggunakan 2 (dua) sampel sudah diperoleh rata-rata guna hasil akhir Sand Equivalent (SE) ialah $96,69 \%$ dan tingkat lumpur 3,31\%. Keduaduanya memenuhi Spesifikasi secara Umum Bina Marga 2018 ialah minimal 60\%.

Percobaan partikel kepipihan serta kelonjongan agregat kasar didapatkan dari hasil partikel pipih adalah $8,46 \%, 2,41 \%, 0,51 \%$, dan $0 \%$. Partikelprtikel lonjong adalah 1,04\%, 5,99\%, 0,46\% dan $0 \%$. Dengan ketentuan maksimal $10 \%$.

Dari percobaan kelekatan agregat terkait aspal. percobaan tersebut hanya bersifat visualisasi/kasat mata yang tidak melewati prosedur perhitungan Hasil dari luas permukaan sampel yang diseliuti aspal (kurang dari 95\%/lebih dari 95\%). Artinya bisa melekat baiik pada agregat.

\section{b. Aspal}

Jenis aspal yang dipakai didalam percobaan ini ialah aspal penetrasi 60/70. Dari hasil akhir percobaan penetrasi didapatkan hasil guna nilai penetrasi $67 \mathrm{~mm}$. Berdasarkan standar Umum Bina Marga 2018 nilai minimal $60(0,1)$ $\mathrm{mm}$ - maksimum $70(0,1) \mathrm{mm}$. Dari nilai akhir Percobaan daktilitas didapatkan hasil akhir ratarata $150 \mathrm{~cm}$. Hasil dari Percobaan titik lembek aspal diperoleh nilai rpatarata $50,2^{\circ} \mathrm{C}$ ketentuan yaitu antara $48-58^{\circ} \mathrm{C}$. ercobaan di titik nyala diperoleh dari nilai akhir ratarata $290^{\circ} \mathrm{C}$. Hasil percobaan berat jenis diperoleh nilai rata-rata $1,015 \mathrm{gr} / \mathrm{cc}$. Hasil percobaan penurunan berat aspal didapatkan nilai rata-rata $0,434 \%$ yang mana ketentuan maksimum $0,8 \%$. Hasil percobaan penetrasi pada TFOT diperoleh nilai rata-rata 84,7\%. Dengan ketentuan Min $54 \%$.

\section{Marshall Konvensional}

Dari semua benda uji dapatkan dari kadar aspal untuk AC-WC yaitu: " $5,00 \%, 5.5 \%, 6,00 \%, 6,5 \%$, 7,00\%". Hasil dari perhitungan bulk spesific gravity dan effective spesific gravity bisa dilihat berikut ini pada Tabel 3. 
Tabel 3. Bulk Spesific Gravity dan Effective Spesific Gravity.

AC-WC

\begin{tabular}{lccccc}
\cline { 2 - 6 } Kadar Aspal & 5 & 5.5 & 6 & 6.5 & 7 \\
\hline $\begin{array}{l}\text { Bulk Spesific } \\
\text { Gravity }\end{array}$ & 2.84 & 2.85 & 2.87 & 2.88 & 2.90 \\
$\begin{array}{l}\text { Aggrerate } \\
\text { Effective Spesific }\end{array}$ & & & & & \\
$\begin{array}{l}\text { Gravity } \\
\text { Aggrerate }\end{array}$ & 2,88 & 2.90 & 2.91 & 2.93 & 2.94 \\
\hline
\end{tabular}

Dari hasil percobaan kriteria marshallnkonvensional yang berisi Stabilitas, Void in Mix, Flow, Void in Mineral Aggregate, dan VFB bisa dilihat pada Tabel 4.

Tabel 4. Nilai karakteristik marshall konvensional

\begin{tabular}{cccccc}
\hline Persyaratan & $\begin{array}{c}3-5 \\
(\%)\end{array}$ & $\begin{array}{c}\text { Min 800 } \\
(\mathrm{kg})\end{array}$ & $\begin{array}{c}\text { Min 65 } \\
(\%)\end{array}$ & $\begin{array}{c}2-4 \\
(\mathrm{~mm})\end{array}$ & $\begin{array}{c}\text { Min } \\
15 \\
(\%)\end{array}$ \\
\hline $\begin{array}{c}\text { Kadar Aspal } \\
(\%)\end{array}$ & VIM & Stabilitas & VFB & Flow & VMA \\
\hline 5 & 4,678 & 1581,62 & 70,20 & 3,40 & 15,69 \\
5,5 & 4,366 & 2031,61 & 73,75 & 2,92 & 16,63 \\
6 & 3,826 & 2137,27 & 77,97 & 2,55 & 17,37 \\
6,5 & 3,392 & 1988,38 & 81,36 & 2,93 & 18,20 \\
7 & 3,278 & 1897,1 & 83,01 & 3,20 & 19,29 \\
\hline
\end{tabular}

a. Void in Mix

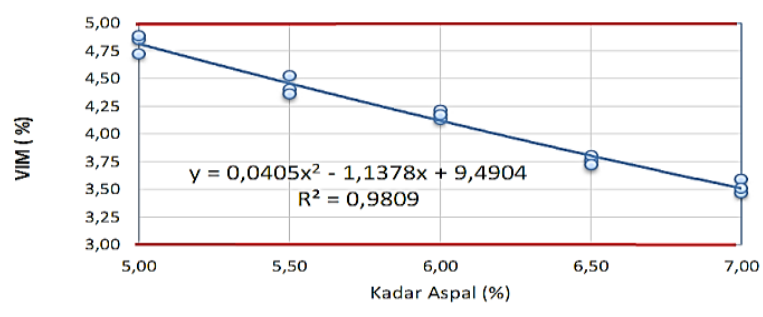

Gambar 3. Hubungan antara VIM dengan kadar aspal

Terliihat bahwa pada pemakaian kadar aspal dari $5 \%$ - 7\%\% didapatkan nilal VIM 4,89\%-3,47\%.Dari Nilai VIM ini telah memenuhi ketentuan.Pada grafiik diatas dapat diketahui pemakaian aspal pada campuran membantu pengisian rongga dlantara campuran yang beraspal.

\section{b. Stabillitas}

Nilai stabilitas diperoleh $1581,625 \mathrm{~kg}-1897,130 \mathrm{~kg}$.

Penggunaan kadar aspal yang sedikit pada campuran AC-WC akan memperoleh seliimut aspal yang tipis, pada permukaan agregat yang mengakilbatkan ikatan agregat Interlocking menjadi lemah sehingga stabillitas pada campuran sangat kecil, tetapi jika aspal bertambah maka selimut aspal menjadi tebal oleh karena itu ikatan antar agregat menjadi kuat/stabiilitas dari campuran besar, selanjutnya apabila aspal mengalami pertambahan sebanyak banyak maka selimut aspal akan semakin tebal yang membuat ikatan antara agregat/stabilitas dalam campuran kembali mengalami penurunan.

\section{c. VFB}

Nilai VFB yang diperoleh yaitu $20 \%-83,01 \%$. Hasil itu memenuhi ketentuan yang mana hasil akhir itu dilihat pada pada grafik kaitan terhadap tingkat aspal seperti pada gambar 4 .

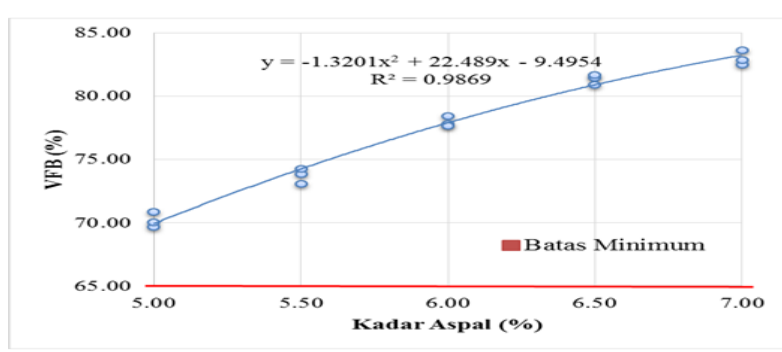

Gambar 4. Kaitan antara VFB terhadap kadar aspal

VFB akan mengalami peningkatan jika tingat kadar dari aspal yang dipakai tinggi. Aspal didalam campuran akan terisi rongga yang ada dalam campuran agregat.

\section{d. Flow}

Nilai kelelehan diperoleh $40 \mathrm{~mm}$ - 19,29 mm.

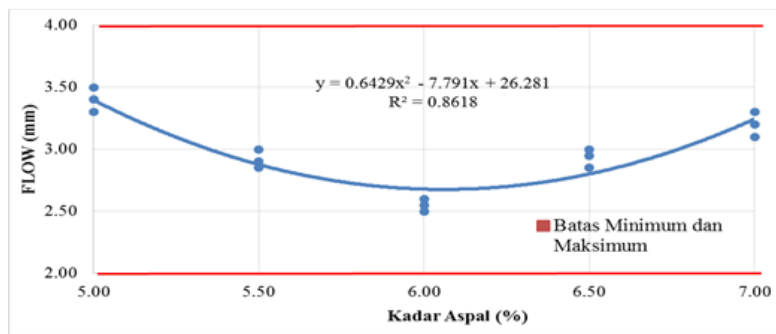

Gambar 5. Hubungan antara flow dengan kadar aspal

Penggunaan aspal didalam campuran beraspal sangatlah kecil supaya ikatan antar agregatnya mengalami pengecilan dan membuat kelelehan yang besar. Apabila pemakaian aspal mengalami penambahan banyak supaya ikatan agregat didalam campuran menjadi lebiih kuat yang membuat kelelehan campuran semakin menurun, selanjutnya jika pemakaian aspal mengalami penambahan banyak lagi supaya selimut aspal menjadi lebih tebal dan mengakibatkan daya campuran semakin berkurang akan tetapi keleleehan bertambah besar, yang berarti kekuatan campuran/stabilitas akan mempunyai 
perbandingan terbalik terhdap kelelehan pada campuran / Flow.

\section{e. Void in Mineral Aggregate}

Dengan memakai tingkat kadar aspal yang dipergunakan 5,\% - 7\% didapatkan hasil akhir VIM antara 4,68\% - 3,28\%. Semakin tinggi tingkat kadar aspal yang dipergunakan supaya hsil akhir VIM yang semakin kecil begitu pula sebaliknya, apabila kadar aspal yang dipakai semakin kecil supaya hasil akhir VIM semakin besar, kerena fungsi aspal sebagai pengiikat dan pengisl dalam rongga campuran beraspal.

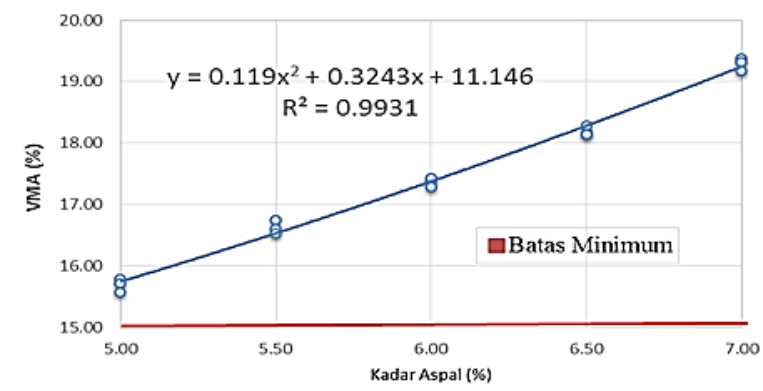

Gambar 6. Hubungan antara VMA dengan kadar aspal

\section{Penetapan Kadar Aspal Optimum}

Kriteria campuran yang memakai metoda marshall campuran serta kadar aspal praktis tersebut ialah kesenjangan kadar aspal $5 \%-7 \%$. Hasil VIM yang paling kecil ialah pada kadar aspal $7 \%$ karena fungsi campuran ACWC ialah lapisan pelindung untuk itu dengan semakin bertambah kecilnya nilai VIM diharapkan campuran lebih kedap air

\section{Stabilitas Marshall Sisa}

Dari hasil indeks kekuatan didapatkan hasil percobaan rasio terhadap perbandingan stabilitas atas benda uji Marshall yang direndam dalam suhu $60^{\circ} \mathrm{C}$ dalam waterbath selama 24 jam pada stabilitas benda uji Marshall dengan perendaman 30 menit bisa juga disebut Stabilltas Marshall Sisa.

Menurut nilai percobaan Marshall Immersion diperoleh hasil Stabilitas Marhsall Sisa sebesar 97,72\% guna AC-WC dengan tingkat kadar aspal $7 \%$. Nilai Stabilitas Marshall Sisa sudah mematuhi dasar yang ditentukan oleh Spesifikasi Umum Bina Marga 2018 ialah $\geq 90 \%$. Perkerasan jalan yang memakai agregat dari Sungai Melli Kecamatan Baebunta dalam campuran AC-WC dapat tahan terhadap temperatur dan lamanya terendam dalam air.

\section{KESIMPULAN}

Karakteristik agregat dan pasir yang berasal dari
Sungai Melli Kecamatan Baebunta serta aspal penetrasi 60/70 dan berat jenis filler (semen) memenuhi persyaratan untuk campuran AC-WC Berdasarkan Spesifikasi Umum Bina Marga 2018. Komponen campuran AC-WC yang dipakai adalah kadar aspal yang memiliki nilai optimum $7 \%$ dimana komposisi gradasi agregat yang dipakai ditentukan berdasarkan nilai vim terendah dengan memperhatikan nilai agregat kasar, nilai agregat halus serta filler.

Hasil pengujian Marshall Immersion (Stabilitas Marshall Sisa) dari campuran AC-WC yang memakail agregat darl Sungai Melli Kecamatan Baebunta Kabupaten Luwu Utara telah memenuhl Spesifikasi Umum Bina Marga Tahun 2018, yaitu $97,2 \% \geq 90 \%$.

\section{DAFTAR PUSTAKA}

[1] Anonim,2020, Pedoman Penyusunan "Laporan Tugas Akhir", Jurusan Teknik Sipil Fakultas Teknik UKI Paulus, Makassar.

[2] Paris, Luther, 2016. Uji Karakteristik Marshall Campurann Laston AC-WC Dengan Menggunakan Limbah Cangkang Kepiiting

[3] Daud, Rachman R, Tanijaya J., 2020., "Study of the use Bagasse ash as a filler", $3^{\text {nd }}$ International on Civil and Environmental Engineerlng (ICCEE)., IOP Conf. Series: Earth and Environmental Science 419012035 doi: 10.1088/1755- 1315/419/1/012035.

[4] Alpius, 2020., Characteristics of Marshall Additional Hot Rolled Sheed Base Rattan Fiber", ICCEE 2019 IOP Conf. Ser.: Earth Environ. Sci. 419012189 doi: 10.1088/17551315/419/1/012089

[5] L.A,F., Irianto, Eliizabeth, dan Alpius, 2019.,"Pemanfaatan Agregat Sungai Wanggar Kabupaten Nabire Sebagai Bahan Campuran AC-WC Dan AC-BC", Paulus Civil Engineering Journal. Vol.1, No.2

6] Irene Sion Kondo Sosang, Alpius, dan Elizabeth, 2020. "Pemanfaatan Agregat Sungai Mawa Kecamatan Cendana dalam Campuran AC-WC ". Paulus Civil Engineering Journal, Vol.1, No.1

[7] Direktorat Jenderal Bina Marga 2018, "Spesifikasi Umum 2018 untuk pekerjaan konstruksi Jalan dan Jembatan Jakarta Indonesia: Kementrian Pekerjaan Umum dan Perumahan Rakyat.

[8] Suardi, Ryeky, 2018. Uji Karakteristiik Marshall Campuran Laston AC-WC Dengan Menggunakan Cangkang Keong Mas Sebagai Pengganti Filler. UKI Paulus, Makassar. 
[9] Wendani ,N.,Selintung,M., dan Alpius, 2020. "Studi Penggunaan Agregat Sungai

[10] Siswoesoebrotho,B.I, 1999, Bahan Bittuang Sebagai Bahan Campuran AcWc".Paulus Civil Engineering Journal Vol. 2 No.2,138-144. 